УДК 575+577.1: 633.1

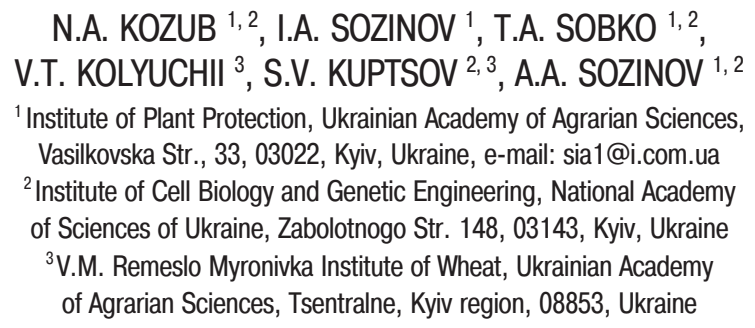

\section{VARIATION AT STORAGE PROTEIN LOCI IN WINTER COMMON WHEAT CULTIVARS OF THE CENTRAL FOREST-STEPPE OF UKRAINE}

Genotypes at the gliadin loci Gli-A1, Gli-B1, Gli-D1 and the high-molecular-weight glutenin subunit loci Glu-A1, GluB1, Glu-D1 were identified in 77 winter common wheat cultivars developed in the Central Forest Steppe of Ukraine in different periods of time. The highest level of variation was observed at the Gli-A1 locus. Predominant alleles (one or two per locus) were revealed. The comparison of allele frequencies in groups of cultivars developed in different periods of time (before 1996 and in 1996-2007) has demonstrated appearance of new alleles and change of frequencies of existing alleles at the storage protein loci. The high frequency of cultivars with the wheat-rye $1 B L / 1 R S$ translocation was detected (about $40 \%$ ). The wheat rye $1 A L / 1 R S$ translocation was identified in six cultivars developed in the last decade. Four gliadin alleles, Gli-A1w (a marker for the 1AL/1RS translocation), Gli-A1x, Gli-Aly and Gli-B1x, were proposed for cataloging.

(C) N.A. KOZUB, I.A. SOZINOV, T.A. SOBKO, V.T. KOLYUCHII, S.V. KUPTSOV, A.A. SOZINOV, 2009
Introduction. Storage proteins are convenient biochemical markers for identification and registration of wheat cultivars, analysis of their purity. Seed storage protein loci in common wheat (Triticum aestivum L.) are well-studied. Alcohol-soluble proteins, gliadins, are encoded by the six major loci Gli-A1, Gli-B1, Gli-D1, Gli-A2, Gli-B2 and Gli-D2 located in the distal parts of the short arms of homoeologous group 1 and 6 chromosomes [1]. These loci are highly polymorphic [2-4]. Loci encoding high-molecular-weight glutenin subunits (HMW GS), Glu-A1, Glu-B1 and Glu-D1, are located on the long arms of homoeologous group 1 chromosomes [5]. They also show multiple allelism $[4,6]$. Storage protein composition shows association with bread-making quality [7].

Investigation of genotypes at storage protein loci permits tracing the history of breeding in different countries. In particular, gliadin diversity was analyzed in collections of common wheat cultivars from different countries of the world: Russia [8, 9], Ukraine [10], North Kazakhstan [11], France [12], Italy [13], England [8], Spain [14], Greece [15] etc. In some studies, predominance of certain alleles depending on the location of breeding centers was demonstrated $[8,11,16]$.

The objective of this study was to analyze variation at the major storage protein loci of homoeologous group 1 chromosomes in winter common wheat cultivars developed in the main breeding center of the Central Forest-Steppe of Ukraine, V.M. Remeslo Myronivka Institute of Wheat, as well as cultivars developed jointly with the Institute of Plant Physiology and Genetics, and to compare allele frequencies in groups of cultivars developed in different periods of time.

Materials and Methods. Seventy seven winter common wheat $T$. aestivum L. cultivars developed in the V.M. Remeslo Myronivka Institute of Wheat (MIW) of the Ukrainian Academy of Agrarian Sciences (UAAS) were analyzed. The cultivars released in different periods of time (before 1996 and in 1996-2007) are listed in Table 1. Most of the cultivars of the second group were bred jointly with the Institute of Plant Physiology and Genetics of the National Academy of Sciences of Ukraine (IPPG), two were bred jointly with the Institute of Plant Protection UAAS (Demetra, Myronivska Storichna). The seeds of the cultivars derived from MIW genetic collections of reproductions of 2002, 2005, 2006 and 2007.

From 10 to 100 single seeds of each cultivar 
were analyzed. Acid polyacrylamide gel electrophoresis of gliadins was performed by the modified procedure of Kozub and Sozinov [17]. Gliadins were extracted with $70 \%$ ethanol (400 $\mu 1$ per caryopsis) for $2 \mathrm{~h} ; 120 \mu \mathrm{l}$ of ethanol extract was sampled and dried at $20-35^{\circ} \mathrm{C}$. Prior to loading, samples were dissolved in $80 \mu \mathrm{l}$ of $5.5 \mathrm{M}$ urea colored with pyronin $\mathrm{Y}$ for $1 \mathrm{~h}$. Gels contained $10 \%$ acrylamide, $0.2 \%$ N', N'-methylene-bis-acrylamide, $3 \mathrm{M}$ urea, $0.17 \mathrm{M}$ acetic acid, $0.1 \% \mathrm{KOH}$, and $0.054 \%$ ascorbic acid. Gels were polymerized using $0.1 \% \mathrm{FeSO}_{4} \cdot 7 \mathrm{H}_{2} \mathrm{O}, 10 \%$ ammonium persulfate, and TEMED: $44 \mu \mathrm{l}, 50 \mu \mathrm{l}$ and $5 \mu \mathrm{l}$, respectively, per $10 \mathrm{ml}$ of gel. The upper and lower electrode solutions were 0.04 and $0.08 \mathrm{M}$ formic acid, respectively. Electrophoresis of HMW GS was carried out by the procedure of Laemmli [18] in $10 \%$ resolving gel. Gliadin alleles were identified using the catalogue of Metakovsky [3] supplemented by alleles presented in further studies [12, 14, 19]. The Gli-B5b allele was identified from the characteristic pattern (two $\omega$-components), as presented in [14]. Cultivars lacking these components carry the Gli-B5a allele (null allele) [12]. Alleles of HMW GS were identified by the catalogue of Payne and Lawrence [6]. The cultivar Bezostaya 1, its near-isogenic line with the Gli-Alm allele [20], as well as some cultivars recommended in [3] were used as gliadin standards.

Allele frequency in groups of cultivars was calculated with consideration for heterogeneous cultivars (the frequency of each of the two alleles at a locus in a heterogeneous cultivar was taken to be $50 \%)$. Standard errors of frequencies were calculated by the formula

$$
S E=\sqrt{p(1-p) / N \cdot 100},
$$

where $p$ is the allele frequency, $N$ is the number of cultivars in the group analyzed [21]. Nei's genetic variation index [22] at each locus was calculated by the formula

$$
H=1-\Sigma p_{i}^{2},
$$

where $p_{i}$ is the frequency of the certain allele at the locus in a group studied. Average values of $H$ were calculated for three Gli-1 loci, three Glu-1 loci and all six loci.

Results. Alleles at the gliadin loci $G l i-A 1$, Gli$B 1, G l i-D 1$ and the HMW GS loci Glu-A1, Glu-B1, $G l u-D 1$ in winter common wheat cultivars of the Central Forest-Steppe of Ukraine are presented in
Table 1. The cultivars were released in different periods of time: 28 before 1996 and 49 in 1996-2007. About $25 \%$ of cultivars are heterogeneous at one or more storage protein loci (Table 1).

In the total group of cultivars, the highest number of alleles (eight) was detected at the Gli-A1 locus. Seven alleles were detected at the Gli-B1 and Gli$D 1$ loci. At the HMW GS loci variation was lower: five alleles the $G l u-B 1$ locus and three alleles at the Glu-A1 and Glu-D1 loci (Table 2). At the Gli-A1 locus, three alleles $(f, b$ and $o$ ) predominate with similar frequencies. At the Gli-B1 locus, predominant alleles are $b$ and $l$, each found in about $40 \%$ of cultivars. The $G l i-B 1 l$ allele is a marker for the wheat-rye $1 \mathrm{BL} / 1 \mathrm{RS}$ translocation $[3,23]$. At the Gli-D1 locus, the allele $b$ predominates in the total sample with the frequency of $65 \%$, the second is the allele $g$ (about $19 \%$ ). At $G l u-A 1$, the alleles $a$ and $b$ have similarly high frequencies, whereas at $G l u-B 1$ and $G l u-D 1$, the alleles $c$ and $d$, respectively, predominate.

Four gliadin alleles identified in the Ukrainian Forest-Steppe cultivars (Gli-A1w, Gli-A1x, Gli-A1y and $G l i-B 1 x)$ are absent in the basic catalogue of Metakovsky [3] and among alleles presented in further studies [12, 14, 19], as well as in the last version of the Catalogue of Gene Symbols [4]. Electrophoretic patterns of these alleles are given in Figure. The allele Gli-Alw (a specific secalin block) is a marker of the wheat-rye $1 \mathrm{AL} / 1 \mathrm{RS}$ translocation that first appeared in the cultivar Amigo. This translocation was much studied previously. Its pattern was included in the catalogue of Sobko and Poperelya [2] (starch gel) as the allele $G L D-1 A$ 17. The allele $G l i-A 1 w$ was found in six cultivars of the last decade (Expromt, Kolumbia, Zolotokolosa, Vesnyanka, Smuglyanka and Mono$\log$ ) (Table 1). The allele Gli-Aly is an allele that probably arose from recombination of the alleles Gli-Alb and Gli-Alf. It looks like the allele Gli-Alb with the faint $\omega$-gliadin components from the allele Gli-Alf. It was found in Mironovskaya 25, Mironovskya 29 and Vdyachna and corresponds to the allele $G L D-1 A 12$ according to the previous nomenclature [2]. The pattern of the allele Gli-A1x has a $\gamma$-gliadin component with the slightly lower mobility than that of the wide-spread allele GliAlf, but lacks any $\gamma$-components. This allele is present in the catalogue of Sobko and Poperelya [2] as $G L D-1 A$ 9. The allele $G l i-B 1 x$ was identified 
Alleles at storage protein loci in Ukrainian Central Forest-Steppe winter common wheat cultivars

\begin{tabular}{|c|c|c|c|c|c|c|}
\hline \multirow{2}{*}{ Cultivar } & \multicolumn{6}{|c|}{ Alleles at loci } \\
\hline & Gli-Al & $G l i-B l$ & $G l i-D l$ & Glu-Al & Glu-Bl & $G l u-D l$ \\
\hline \multicolumn{7}{|c|}{ Developed before 1996} \\
\hline Ilichevka & $f$ & $b$ & $b$ & $a$ & $c$ & $d$ \\
\hline Komsomolskaya 56 & $c$ & $b$ & $b$ & $a$ & $c$ & $d$ \\
\hline Mirleben & $o$ & $l$ & $l$ & $c$ & $c$ & $d$ \\
\hline Mironovskaya 11 & $b$ & $b$ & $b$ & $b$ & $c$ & $d$ \\
\hline Mironovskaya 19 & $f$ & $l+b$ & $l+b$ & $b+a$ & $c$ & $d$ \\
\hline Mironovskaya 25 & $y$ & $b$ & $b$ & $b$ & $c$ & $d$ \\
\hline Mironovskaya 264 & $c$ & $b$ & $b$ & $a$ & $c$ & $d$ \\
\hline Mironovskaya 29 & $y$ & $d$ & $d$ & $a$ & $c$ & $d$ \\
\hline Mironovskaya 40 & $f$ & $b$ & $b$ & $a$ & $c$ & $d$ \\
\hline Mironovskaya 61 & $f+x$ & $l$ & $l$ & $a+b$ & $c$ & $d$ \\
\hline Mironovskaya 62 & $f$ & $x$ & $x$ & $b$ & $c$ & $d$ \\
\hline Mironovskaya Poluintensivnaya & $o$ & $f$ & $f$ & $b$ & $a$ & $d$ \\
\hline Mironovskaya Yubileinaya & $f$ & $b$ & $b$ & $a$ & $c$ & $d$ \\
\hline Mironovskaya 10 & $o$ & $l$ & $l$ & $a$ & $c$ & $d$ \\
\hline Mironovskaya 808 & $f$ & $b$ & $b$ & $a$ & $c$ & $d$ \\
\hline Myrkhad & $o$ & $e$ & $e$ & $c$ & $c$ & $a$ \\
\hline Myronivska 27 & $b+x$ & $l+b$ & $l+b$ & $b$ & $c$ & $d$ \\
\hline Myronivska 28 & $o$ & $l$ & $l$ & $a$ & $c$ & $d$ \\
\hline Myronivska 30 & $b$ & $l$ & $l$ & $b$ & $c$ & $d$ \\
\hline Myronivska 32 & $f$ & $b$ & $b$ & $b+a$ & $c$ & $d$ \\
\hline Myronivska 34 & $f$ & $b$ & $b$ & $c$ & $c$ & $d$ \\
\hline Myronivska 63 & $f$ & $d+l$ & $d+l$ & $a+b$ & $c$ & $d$ \\
\hline Myronivska 65 & $c$ & $l$ & $l$ & $b$ & $c$ & $d$ \\
\hline Myronivska 66 & $f$ & $b$ & $b$ & $c+b$ & $c$ & $d$ \\
\hline Myronivska Ostysta & $o$ & $b$ & $b$ & $b$ & $c$ & $d$ \\
\hline Myrych & $f$ & $l$ & $l$ & $c$ & $c$ & $d$ \\
\hline Ukrainka 0246 & $c$ & $b$ & $b$ & $a$ & $c$ & $a+d$ \\
\hline Volgogradskaya 84 & $b$ & $b$ & $b$ & $a$ & $c$ & $d$ \\
\hline \multicolumn{7}{|c|}{ Developed in 1996-2007 } \\
\hline Bagira & $x$ & $l$ & $b$ & $a$ & $c$ & $d$ \\
\hline Bogdana & $o$ & $b$ & $b$ & $a$ & $c$ & $d$ \\
\hline Dashenka & $f$ & $f$ & $b$ & $b$ & $c$ & $a$ \\
\hline Demetra & $b$ & $b+l$ & $b$ & $b$ & $c$ & $d$ \\
\hline Ekonomka & $b$ & $b+l$ & $b$ & $b$ & $c$ & $d$ \\
\hline Ekspromt & $w$ & $b$ & $b$ & $b$ & $d$ & $a$ \\
\hline Estet & $f$ & $h$ & $b$ & $b$ & $a$ & $e+a$ \\
\hline Favoritka & $o$ & $l$ & $b$ & $c$ & $c$ & $d$ \\
\hline Garant & $o$ & $h$ & $b$ & $c$ & $c+i$ & $d$ \\
\hline Garazivka & $o$ & $l$ & $g$ & $a+c$ & $c$ & $d$ \\
\hline Kalynova & $f$ & $l$ & $b$ & $b$ & $c$ & $d$ \\
\hline Khazarka & $m$ & $l$ & $b$ & $a$ & $c$ & $d$ \\
\hline Khurtovyna & $b$ & $b$ & $b$ & $a$ & $c$ & $d$ \\
\hline Kolos Myronivshchyny & $b$ & $l$ & $b$ & $b$ & $c$ & $d$ \\
\hline Kolumbia & $w$ & $b$ & $b$ & $b$ & $d$ & $a$ \\
\hline Kryzhynka & $x$ & $l$ & $b$ & $a+b$ & $c$ & $d$ \\
\hline Kyivska 7 & $f$ & $l$ & $b$ & $b$ & $c$ & $d$ \\
\hline Kyivska 8 & $b$ & $b$ & $j$ & $a$ & $b$ & $d$ \\
\hline Lasunya & $x$ & $b$ & $j$ & $c$ & $b$ & $d$ \\
\hline
\end{tabular}


Continued Table 1

\begin{tabular}{|c|c|c|c|c|c|c|}
\hline \multirow{2}{*}{ Cultivar } & \multicolumn{6}{|c|}{ Alleles at loci } \\
\hline & $G l i-A l$ & $G l i-B l$ & $G l i-D l$ & Glu-Al & $G l u-B l$ & $G l u-D l$ \\
\hline \multicolumn{7}{|c|}{ Developed in 1996} \\
\hline Maritsa & $b$ & $l$ & $b$ & $b$ & $c$ & $d$ \\
\hline Modus & $b$ & $h$ & $b$ & $a$ & $d$ & $d$ \\
\hline Monolog & $w$ & $d$ & $f$ & $b$ & $c$ & $d$ \\
\hline Monotyp & $f$ & $h$ & $b$ & $b$ & $a$ & $E$ \\
\hline Myronivska 31 & $c$ & $b$ & $b$ & $a$ & $c$ & $d$ \\
\hline Myronivska 33 & $o$ & $l$ & $g$ & $b$ & $c$ & $d$ \\
\hline Myronivska 67 & $f$ & $l$ & $b$ & $a$ & $c$ & $d$ \\
\hline Myronivska Ranniostygla & $b$ & $b$ & $f$ & $a$ & $c$ & $d$ \\
\hline Myronivska Storichna & $f$ & $x$ & $b$ & $b$ & $c$ & $d$ \\
\hline Myryanka & $x+f$ & $l$ & $b$ & $a$ & $c$ & $d$ \\
\hline Mytets & $f$ & $b$ & $g$ & $b+a$ & $b$ & $d$ \\
\hline Oktava & $b$ & $e$ & $b$ & $b+c$ & $d$ & $d$ \\
\hline Pereyaslavka & $b$ & $b$ & $g$ & $b$ & $b$ & $d$ \\
\hline Podolyanka & $o$ & $b$ & $b$ & $a$ & $c$ & $d$ \\
\hline Pyvna & $o$ & $l$ & $l$ & $a$ & $c$ & $d$ \\
\hline Remeslivna & $b$ & $b$ & $b$ & $b$ & $b$ & $d$ \\
\hline Smuglyanka & $w$ & $b$ & $b$ & $a$ & $d$ & $a$ \\
\hline Snigurka & $o$ & $b$ & $b$ & $a$ & $c$ & $d$ \\
\hline Snizhana & $b$ & $l$ & $f$ & $b$ & $c$ & $d$ \\
\hline Svyatkova & $x$ & $l$ & $b$ & $b$ & $c$ & $d$ \\
\hline Troyan & $f$ & $l$ & $b+g$ & $a$ & $a$ & $d$ \\
\hline Vdyachna & $y$ & $d$ & $f$ & $a$ & $c$ & $d$ \\
\hline Vesnyanka & $w$ & $b$ & $b$ & $b$ & $d$ & $d$ \\
\hline Vesta & $b$ & $l$ & $b$ & $b$ & $c$ & $d$ \\
\hline Volodarka & $o+b$ & $b+l$ & $b$ & $a+b$ & $c+b$ & $d$ \\
\hline Voloshkova & $x$ & $l$ & $b$ & $a$ & $c$ & $d$ \\
\hline Volynska 2 & $f$ & $l$ & $i$ & $a$ & $b$ & $d$ \\
\hline Volynska Napivintensivna & $o$ & $l$ & $b+g$ & $c$ & $c$ & $d$ \\
\hline Zolotokolosa & $w$ & $b$ & $b$ & $b$ & $d$ & $a$ \\
\hline Zymoyarka & $c$ & $f$ & $b$ & $a$ & $c$ & $a$ \\
\hline
\end{tabular}

in Mironovskaya 62 and Myronivska Storichna. Its $\gamma$-component has slightly lower mobility than that of the alleles Gli-B1b,j,e, $g$ and $c$ with $\gamma-45$ and its $\omega$-gliadins differ from those in other catalogued alleles. However, it is possible that some of its $\omega$ components marked in Figure might be encoded by minor loci of chromosome $1 \mathrm{~A}$ or $1 \mathrm{~B}$.

The cultivars with the Gli-B1h allele (Estet, Garant, Modus and Monotyp) carry two $\omega$-components with the mobility similar to that of the allele Gli-B5b. Gli-B5 is a minor locus closely linked to the major locus $G l i-B 1$ [24]. Its allele Gli$B 5 b$ is associated with the $R g 1$ allele for the red color of glumes [13]. However, the above four cultivars with $G l i-B 5 b$ have white glumes and thus the $r g 1$ allele. Such cultivars (with the Gli-B5b allele and white glumes) were also previously found among Spanish cultivars (Candeal de Arevalo, Dimas, E. Morandi, a biotype of Negrillo) [14]. At the $G l i-B 5$ locus, the rest of the cultivars carry the Gli-B5a allele (null-allele). However, Mironovskaya 62 and Myronivska Storichna might have another allele at this locus, which has to be proved by genetic analysis.

The comparison of the groups of cultivars developed in different periods of time has demonstrated the appearance of new alleles as well as the change of frequencies of the existing ones. In the group of cultivars developed before 1996, the predominant alleles are $f$ and $o$ at $G l i-A 1, b$ and $l$ at $G l i-B 1, b$ and $g$ at Gli-D1, $a$ and $b$ at Glu-A1, Glu-B1c and Glu$D 1 d$ (Table 2). In the group of cultivars developed 
Table 2

Frequencies $(p)$ of alleles at storage protein loci in groups of Ukrainian Central Forest-Steppe winter common wheat cultivars ( $S E$ is the standard error)

\begin{tabular}{|c|c|c|c|c|c|c|c|}
\hline \multirow{2}{*}{ Locus, alleles } & \multicolumn{2}{|c|}{ Total group } & \multicolumn{2}{|c|}{ Developed before 1996} & \multicolumn{2}{|c|}{ Developed in 1996-2007 } & \multirow{2}{*}{$t^{\mathrm{a}}$} \\
\hline & $p$ & $S E$ & $p$ & $S E$ & $p$ & $S E$ & \\
\hline \multicolumn{8}{|l|}{ Gli-A1 } \\
\hline$b$ & 0.221 & 0.047 & 0.125 & 0.063 & 0.265 & 0.063 & -1.58 \\
\hline$c$ & 0.078 & 0.031 & 0.143 & 0.066 & 0.041 & 0.028 & 1.42 \\
\hline$f$ & 0.286 & 0.051 & 0.411 & 0.093 & 0.214 & 0.059 & 1.79 \\
\hline$m$ & 0.013 & 0.013 & 0.000 & 0.000 & 0.020 & 0.020 & -1.01 \\
\hline$o$ & 0.201 & 0.046 & 0.214 & 0.078 & 0.184 & 0.055 & 0.32 \\
\hline$w$ & 0.078 & 0.031 & 0.000 & 0.000 & 0.122 & 0.047 & $-2.61 * *$ \\
\hline$x$ & 0.084 & 0.032 & 0.036 & 0.035 & 0.133 & 0.048 & -1.62 \\
\hline$y$ & 0.039 & 0.022 & 0.071 & 0.049 & 0.020 & 0.020 & 0.97 \\
\hline \multicolumn{8}{|l|}{$G l i-B 1$} \\
\hline$b$ & 0.422 & 0.056 & 0.536 & 0.094 & 0.357 & 0.068 & 1.53 \\
\hline$d$ & 0.045 & 0.024 & 0.054 & 0.043 & 0.041 & 0.028 & 0.25 \\
\hline$e$ & 0.026 & 0.018 & 0.036 & 0.035 & 0.020 & 0.020 & 0.38 \\
\hline$f$ & 0.039 & 0.022 & 0.036 & 0.035 & 0.041 & 0.028 & -0.11 \\
\hline$h$ & 0.052 & 0.025 & 0.000 & 0.000 & 0.082 & 0.039 & $-2.09 *$ \\
\hline$l$ & 0.390 & 0.056 & 0.304 & 0.087 & 0.439 & 0.071 & -1.21 \\
\hline$x$ & 0.026 & 0.018 & 0.036 & 0.035 & 0.020 & 0.020 & 0.38 \\
\hline \multicolumn{8}{|l|}{ Gli-D1 } \\
\hline$a$ & 0.013 & 0.013 & 0.036 & 0.035 & 0.000 & 0.000 & 1.02 \\
\hline$b$ & 0.649 & 0.054 & 0.500 & 0.094 & 0.735 & 0.063 & $-2.07 *$ \\
\hline$f$ & 0.097 & 0.034 & 0.125 & 0.063 & 0.082 & 0.039 & 0.59 \\
\hline$g$ & 0.188 & 0.045 & 0.339 & 0.089 & 0.102 & 0.043 & $2.39 *$ \\
\hline$i$ & 0.013 & 0.013 & 0.000 & 0.000 & 0.020 & 0.020 & -1.01 \\
\hline$j$ & 0.026 & 0.018 & 0.000 & 0.000 & 0.041 & 0.028 & -1.44 \\
\hline$l$ & 0.013 & 0.013 & 0.000 & 0.000 & 0.020 & 0.020 & -1.01 \\
\hline \multicolumn{8}{|l|}{ Glu-A1 } \\
\hline$a$ & 0.442 & 0.057 & 0.464 & 0.094 & 0.429 & 0.071 & 0.30 \\
\hline$b$ & 0.435 & 0.056 & 0.375 & 0.091 & 0.469 & 0.071 & -0.81 \\
\hline$c$ & 0.123 & 0.037 & 0.161 & 0.069 & 0.102 & 0.043 & 0.72 \\
\hline \multicolumn{8}{|l|}{ Glu-B1 } \\
\hline$a$ & 0.052 & 0.025 & 0.036 & 0.035 & 0.061 & 0.034 & -0.52 \\
\hline$b$ & 0.084 & 0.032 & 0.000 & 0.000 & 0.133 & 0.048 & $-2.74 * *$ \\
\hline$c$ & 0.766 & 0.048 & 0.964 & 0.035 & 0.653 & 0.068 & $4.07 * * *$ \\
\hline$d$ & 0.091 & 0.033 & 0.000 & 0.000 & 0.143 & 0.050 & $-2.86 * *$ \\
\hline$i$ & 0.006 & 0.009 & 0.000 & 0.000 & 0.010 & 0.014 & -0.71 \\
\hline \multicolumn{8}{|l|}{ Glu-D1 } \\
\hline$a$ & 0.104 & 0.035 & 0.054 & 0.043 & 0.133 & 0.048 & -1.23 \\
\hline$d$ & 0.877 & 0.037 & 0.946 & 0.043 & 0.837 & 0.053 & 1.62 \\
\hline$e$ & 0.019 & 0.016 & 0.000 & 0.000 & 0.031 & 0.025 & -1.24 \\
\hline
\end{tabular}

a Value of Student's test $(t)$ for the difference between allele frequencies in the groups of varieties developed in different periods of time. ${ }^{*}, * *, * * *$ significant at $\mathrm{P}<0.05, \mathrm{P}<0.01, \mathrm{P}<0.001$, respectively.

in 1996-2007, most of these alleles retained their high frequencies: Gli-Alf, $b$ and $l$ at Gli-B1, Gli-D1b, $a$ and $b$ at Glu-A1, Glu-B1c and Glu-D1d. However, in the 1996-2007 group, the frequency of the allele $G l i-D 1 b$ significantly increased $(\mathrm{P}<0.05)$, whereas the frequency of the allele $G l i-D 1 g$ became lower $(\mathrm{P}<0.05)$ - only $10 \%$; the frequency of the predominant allele Glu-B1c also decreased $(\mathrm{P}<$ 


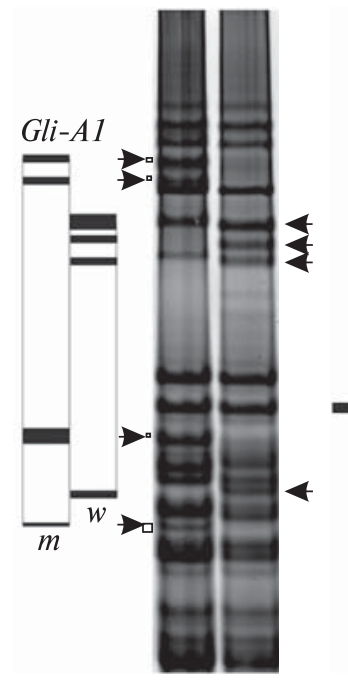

12

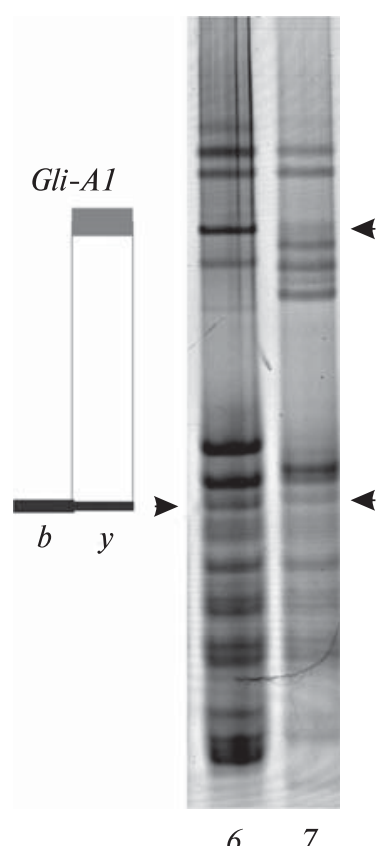

$6 \quad 7$

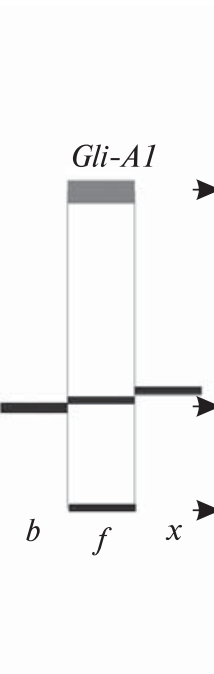

3

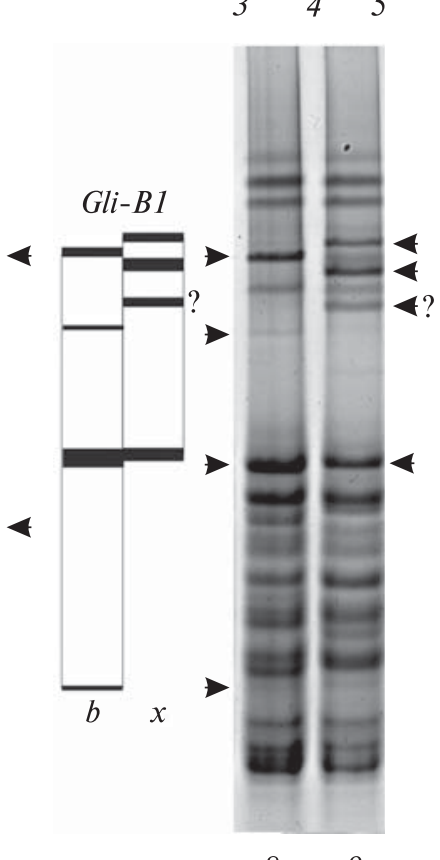

89

Newly-catalogued gliadin alleles $G l i-A 1 w, G l i-A 1 x, G l i-A 1 y$, Gli-B1x identified in Ukrainian Forest-Steppe cultivars. APAG patterns of the Bezostaya 1 near-isogenic line with the allele $G l i-A 1 m$ (lane 1), the cultivars Zolotokolosa with the allele Gli-Alw (2), Myronivska 67 with Gli-Alf (3), Bezostaya 1 with $G l i-A 1 b, G l i-B 1 b(4,6,8)$, Lasunya with $G l i-A 1 x$ (5), Mironovskaya 29 with Gli-Aly (7), Mironovskaya 62 (9) with Gli-B1x. Components of the alleles are marked by arrows, schemes of the alleles are given on the left of the electrophoretic patterns

$<0.001)$. In the group of cultivars of the last decade, there is a tendency for the increase in the frequen-

Table 3

Indices of genetic diversity $(H)$ in groups of Ukrainian Central Forest-Steppe winter common wheat cultivars

\begin{tabular}{l|c|c|c}
\hline \multirow{2}{*}{\multicolumn{1}{c|}{ Locus }} & \multicolumn{3}{|c}{$H$} \\
\cline { 2 - 4 } & $\begin{array}{c}\text { Total } \\
\text { group }\end{array}$ & Before 1996 & $\begin{array}{c}\text { In } \\
1996-2007\end{array}$ \\
\hline Gli-A1 & 0.808 & 0.743 & 0.815 \\
Gli-B1 & 0.662 & 0.613 & 0.669 \\
Gli-D1 & 0.533 & 0.618 & 0.440 \\
Glu-A1 & 0.600 & 0.618 & 0.586 \\
Glu-B1 & 0.395 & 0.069 & 0.532 \\
Glu-D1 & 0.220 & 0.101 & 0.281 \\
Average for Gli-1 & 0.668 & 0.658 & 0.641 \\
Average for Glu-1 & 0.405 & 0.263 & 0.466 \\
Average & 0.536 & 0.461 & 0.554 \\
\hline
\end{tabular}

cy of the allele $G l i-A 1 b$ and the decrease in the frequency of the allele Gli-Blb. A number of new alleles appeared among the cultivars of the last decade. These are Gli-Alw (the 1AL/1RS translocation), Gli-Blh associated with $G l i-B 5 b$ and $r g 1$, Glu-B1d, as well as Glu-B1b, Gli-D1j, Gli-D1i, GliD1l, Glu-Dle, and Glu-B1i (in a biotype of Garant). The allele Gli-D1a was identified in the old cultivar Ukrainka 0246 (released in 1929) by starch electrophoresis but it was not found in the later cultivars.

Analysis of genetic diversity using Nei's index (Table 3) revealed close values of average diversity in two groups of cultivars. However, the average diversity for HMW GS loci increased in the last decade from 0.263 to 0.466 mainly due to the increase in the variation index at the $G l u-B 1$ locus (from 0.069 to 0.532 ), in contrast to the average diversity at the gliadin loci $G l i-1$, which remained stable. Among the Gli-1 loci, Gli-A1 shows the highest indices of variation in both the groups of cultivars $(0.713$ and $0.815)$. Of all the loci studied, the only locus at which the index of variation decreased is Gli-D1 (from 0.618 to 0.440 ).

Discussion. Ukraine has two geographical-climatic zones of wheat cultivation - the Steppe (the southern zone) and the Forest Steppe (the more northern zone). This study deals with the cultivars bred in the main Forest-Steppe center of wheat breeding with the 100-year history- the V.M. Remeslo Myronivka Institute of Wheat. Its breeding history began from the cultivar Ukrainka 0246 released in 1929. The most famous cultivar is Mironovskaya 808 . Beginning from the middle 1990s 
most of the cultivars were developed in cooperation with IPPG. The results of analysis of genotypes at storage proteins loci demonstrate the increase in the number of alleles in the group of the Central Forest-Steppe winter common wheat cultivars developed in the last decade in comparison with the preceding group. However, none of the new alleles became predominant. Genetic diversity remains higher at the gliadin loci in comparison with that at HMW GS loci. The average level of diversity remains stable, but the qualitative and quantitative composition of alleles at some storage protein loci undergoes changes (Tables 2 and 3).

The predominant alleles at the HMW GS loci (Glu-Ala, Glu-A1b, Glu-B1c and Glu-D1d) are identical in both the groups of cultivars and are associated with high-bread-making quality [25]. A special feature of Ukrainian Central Forest-Steppe cultivars in the high frequency of cultivars with the wheat-rye $1 \mathrm{BL} / 1 \mathrm{RS}$ translocation. Its frequency even shows the tendency for increasing (from 30 to $44 \%$ ) despite its well-known deleterious effect on grain quality [26]. The 1BL/1RS translocation, the most wide-spread alien translocation among commercial wheat cultivars [27], carries a number of disease resistance genes: $\operatorname{Pm} 8, \operatorname{Sr} 31, \mathrm{Lr} 26$ and $\mathrm{Yr} 9$ [4]. However, the adaptive value of this translocation cannot be explained by the presence of resistance genes only. The positive effect of 1BL/1RS translocation on yield components and yield stability was demonstrated in some studies [28-31]. The data on the high frequency of the allele $G i i-B 1 l$ (the $1 \mathrm{BL} / 1 \mathrm{RS}$ translocation) in the Ukrainian Central Forest-Steppe cultivars are in good agreement with the data obtained for French cultivars. Metakovsky and Branlard [12] revealed the high frequency of the allele Gli-B1l among cultivars grown in the North of France, which are more resistant to cold.

Cultivars of the last decade show the increase in the frequency of the allele Gli-D1b and the substantial reduction in the frequency of the allele Gli-Dlg. According to the data of Sozinov and Poperelya [32], the allele Gli-DIg (GLD 1D 5) is associated with higher frost resistance. However, the frequency of newly-developed Central Forest-Steppe cultivars with this allele became low, which may reflect the global tendency for warming, and thus, the loss of the adaptive value of this allele.

Of interest is the appearance of cultivars with the wheat-rye $1 \mathrm{AL} / 1 \mathrm{RS}$ translocation, whose mar- ker is a specific secalin block. We propose to include this allele as $G l i-A l w$ to the catalogue of Gli-A1 alleles, like in the case of the allele Gli-B1l. The translocation that derives from Amigo (from the rye Insave) carries the genes for resistance to greenbug Schizaphis graminum biotypes B and C, $G b 2$, to wheat curl mite Aceria tosicheilla (Keifer), $\mathrm{Cm} 3$, to powdery mildew, $\mathrm{Pm} 17$ [4]. It does not have such a deleterious effect on bread-making quality in hard wheat as the $1 \mathrm{BL} / 1 \mathrm{RS}$ translocation does [33].

Previous investigations have demonstrated association of allele variants of storage proteins loci with quality indices as well as productivity and adaptation traits (see review [35]). The results of the investigation of the Ukrainian Central ForestSteppe cultivars indicate fixation of certain storage protein alleles and formation of allele associations. Whereas the composition of HMW GS stems from requirements for high bread-making quality, the high frequency of the 1BL/1RS translocation in this group of cultivars suggests its adaptive value. The change of allele frequencies and involvement of new alleles may reflect changes in the breeding process due to change of climatic conditions and field management factors.

Н.А. Козуб, И.А. Созинов, Т.А. Собко, В.Т. Колючий, С.В. Купцов, А.А. Созинов

ИЗМЕНЧИВОСТЬ ПО ЛОКУСАМ ЗАПАСНЫХ БЕЛКОВ У СОРТОВ ОЗИМОЙ МЯГКОЙ ПШЕНИЦЫ ЦЕНТРАЛЬНОЙ ЛЕСОСТЕПИ УКРАИНЫ

Проанализированы генотипы по глиадиновым локусам Gli-A1, Gli-B1, Gli-D1 и локусам высокомолекулярных субъединиц глютенинов Glu-A1, Glu-B1, GluD1 77 сортов озимой мягкой пшеницы Центральной Лесостепи Украины, созданных в разные периоды времени. Наибольшая изменчивость наблюдалась по локусу $G l i-A 1$. Были определены доминирующие аллели (один-два на локус). Сравнение частот аллелей групп сортов, созданных в разные периоды (до 1996 года и в 1996-2007 годах) позволило выявить появление новых алелей и изменения частот существующих аллелей локусов запасных белков. Наблюдается высокая частота сортов с пшенично-ржаной 1BL/1RS транслокацией (около 40 \%). Ржаную $1 \mathrm{AL} / 1 \mathrm{RS}$ транслокацию имеют шесть сортов, созданных в последнее десятилетие. Предложено внести в каталог четыре глиадиновых аллеля $G l i-A 1 w$ (маркер $1 A L / 1 R S$ транслокации), Gli-A1x, Gli-Aly и Gli-B1x. 


\section{Н.О. Козуб, І.О. Созінов, Т.О. Собко, В.Т. КолючИЙ, С.В. КУпцов, О.О. Созінов \\ МІНЛИВІСТЬ ЗА ЛОКУСАМИ ЗАПАСНИХ БІЛКІВ У СОРТІВ ОЗИМОЇ М'ЯКОЇ ПШЕНИЦІ ЦЕНТРАЛЬНОГО ЛІСОСТЕПУ УКРАЇНИ}

Проаналізовано генотипи за гліадиновими локусами Gli-A1, Gli-B1, Gli-D1 та локусами високомолекулярних субодиниць глютенінів Glu-A1, Glu-B1, GluD1 77 сортів озимої м якої пшениці Центрального Лісостепу України, створених в різні періоди часу. Найбільша різноманітність спостерігалась за локусом Gli$A 1$. Було визначено домінуючі алелі (один-два на локус). Порівняння частот алелів у групах сортів, створених в різні періоди (до 1996 року і в 1996-2007 роках) дозволило виявити появу нових алелів та зміну частот існуючих алелів локусів запасних білків. Спостерігається висока частота сортів з пшенично-житньою 1BL/1RS транслокацією (біля 40 \%). Житню 1AL/1RS транслокацію мають шість сортів, створених в останнє десятиліття. Запропоновано внести в каталог чотири гліадинових алелі Gli-Alw (маркер $1 A L / 1 R S$ транслокаціï), Gli-A1x, Gli-Aly і Gli-B1x.

\section{REFERENCES}

1. Payne P.I. 1987: Genetics of wheat storage proteins and the effect of allelic variation on bread-making quality. Ann. Rev. Plant Physiol. 38: 141-153.

2. Sobko T.A., Poperelya F.A. 1986: The frequency of alleles of gliadin-coding loci in different cultivars of winter common wheat. Visnik Silskogospodarskoi Nauki 5: 84-87. (in Ukrainian).

3. Metakovsky E.V. 1991: Gliadin allele identification in common wheat. II Catalogue of gliadin alleles in common wheat. J. Genet. Breed. 45: 325-344.

4. Mac Gene 2005: Gene Symbols, Gene Classes and References. http://shigen.lab.nig.ac.jp/wheat/komugi/genes/macgene/2005/GeneSymbol.pdf http://shigen.lab.nig.ac.jp/wheat/komugi/genes/macgene/2005/GeneClasses.pdfhttp://shigen.lab.nig.ac.jp/w heat/ komugi/genes/macgene/2005/References.pdf

5. Payne P.I., Holt L.M., Worland A.J., Law C.N. 1982: Structural and genetical studies on the high-molecularweight subunits of wheat glutenin. Part 3. Telocentric mapping of the subunit genes on the long arms of the homoeologous group 1 chromosomes. Theor. Appl. Genet. 63: 129-138.

6. Payne P.I., Lawrence G.J. 1983: Catalogue of alleles for the complex gene loci, Glu-A1, Glu-B1, Glu-D1 which code for high-molecular-weight subunits of glutenin in hexaploid wheat. Cereal Res. Commun. 11: 29-35.

7. Skerritt J.H. 1998: Gluten proteins: genetics, structure and dough quality - a review. AgBiotechNews and Information 10 (8): $247 \mathrm{~N}-270 \mathrm{~N}$.

8. Chernakov V.M., Metakovsky E.V. 1994: Diversity of gliadin-coding locus allelic variants and evaluation of genetic similarity of common wheat varieties from different breeding centers. Genetika 30: 509-517. (in Russian)

9. Novosel'skaya-Dragovich A.Yu., Krupnov V.A., Saifulin R.A., and Pukhalskiy V.A. 2003: Dynamics of genetic variation at gliadin-coding loci in Saratov cultivars of common wheat Triticum aestivum L. over eight decades of scientific breeding. Genetika 39: 1338-1346. (in Russian)

10. Sobko T.A., Sozinov A.A. 1999: Analysis of genotype structure of common wheat cultivars licensed for growing in Ukraine using genetic markers. Tsitologiya $\mathrm{i}$ Genetika 33 (5): 30-41. (in Russian)

11. Metakovsky E.V., Koval S.F., Movchan V.K., Sozinov A.A. 1988: Genetic formulas of gliadin in spring common wheat varieties of North Kazakhstan. Selektsiya i Semenovodstvo 1: 11-13. (in Russian)

12. Metakovsky E.V., Branlard G. 1998: Genetic diversity of French common wheat germplasm based on gliadin alleles. Theor. Appl. Genet. 96: 209-218.

13. Metakovsky E.V., Pogna N.E., Biancardi A.M., Redaelli R. 1994: Gliadin composition of common wheat cultivars grown in Italy. J. Genet. Breed. 48: 55-66.

14. Metakovsky E.V., Gomez M., Vazquez J.F., Carrillo J.M. 2000: High genetic diversity of Spanish common wheats as judged from gliadin alleles. Plant Breed. 119: $37-42$.

15. Xynias I.N, Kozub N.O., Sozinov I.A. 2006: Seed storage protein composition of Hellenic bread wheat cultivars. Plant Breed. 125: 408-410.

16. Sozinov A.A., Sozinov I.A., Kozub N.A., Sobko T.A. 1999: Stable gene associations in breeding and evolution of grasses. In: Wasser SP (ed), Evolutionary Theory and Processes: Modern Perspectives. Papers in Honour of Eviatar Nevo, 97-113. Kluwer Acad. Publ.

17. Kozub N.A., Sozinov I.A. 2000: Distorted segregation at the gliadin locus $G l i-B 1$ in winter common wheat hybrids. Tsitologiya i Genetika 34 (2): 69-76. (in Russian)

18. Laemmli U.K. 1970: Cleavage of structural proteins during assembly of the head of bacteriophage. Nature 227: 680-85.

19. Vaccino P., Metakovsky E.V. 1995: RFLP patterns of gliadin alleles in Triticum aestivum L.: implications for analysis of organization of complex loci. Theor. Appl. Genet. 90: 173-181.

20. Kopus M.M. 1994: Natural gene geography of gliadin alleles in winter common wheat. Selektsiya i Semenovodstvo 5, 9-14. (in Russian)

21. Rokitskii P.F. 1974: Introduction into Statistical Genetics. Vysheishaya Shkola, Minsk. (in Russian)

22. Nei M. 1973: Analysis of gene diversity in subdivided populations. Proc. Nat. Acad. Sci. USA 70: 3321-3323. 
23. Sozinov A.A., Poperelya F.A. 1977: Electrophoresis of gliadin as a method of identification of wheats in which chromosome 1B is completely or partly replaced by rye chromosome 1R. Doklady VASKhNIL 2: 2-4. (in Russian)

24. Pogna N.E., Metakovsky E.V., Redaelli R., Raineri F., Dachkevitch T. 1993: Recombination mapping of Gli-5, a new gliadin-coding locus on chromosomes $1 \mathrm{~A}$ and $1 \mathrm{~B}$ in common wheat. Theor. Appl. Genet. 87: 113-121.

25. Payne P.I., Holt L.M., Jackson E.A., Law C.N. 1984: Wheat storage proteins: their genetics and their potential for manipulation by plant breeding. Philosophical Transactions of Royal Society (London) Ser B, 304: 359-371

26. Finn D., Lukow O.W, Bushuk W., DePauw R.M. 1994: Milling and baking quality of $1 \mathrm{BL} / 1 \mathrm{RS}$ translocation wheats. I. Effects of genotype and environment. Cereal Chem. 71: 189-195.

27. Rabinovich S.V. 1998: Importance of wheat-rye translocations for breeding modern cultivars of Triticum aestivum L. Euphytica 100: 323-340

28. Carver B.F. Rayburn A.L. 1994: Comparison of related wheat stocks possessing 1B or 1RS.1BL chromosomes: Agronomic performance. Crop Sci. 34: 1505-1510.

29. Schlegel R., Meinel A. 1994: A quantitative trait locus
(QTL) on chromosome arm 1RS of rye and its effect on yield performance of hexaploid wheat. Cereal Res. Communs. 22: 7-13.

30. Moreno-Sevilla B., Baenziger P.S., Peterson C.J., Graybosch R.A., McVey D.V. 1995: The 1BL/1RS translocation: Agronomic performance of F3-derived lines from a winter wheat cross. Crop. Sci. 35: $1051-1055$.

31. Villareal R.L., Del-Toro E., Mujeeb-Kazi A., Rajaram S. 1995: The 1BL/1RS chromosome translocation effect on yield characteristics in a Triticum aestivum L. cross. Plant Breed. 114: 497-500.

32. Sozinov A.A., Poperelya F.A. 1979: Prolamin polymorphism and breeding. Vestnik Selskokhozyaistvennoi Nauki 10: 21-34. (in Russian).

33. Graybosch R.A., Peterson C.J., Hansen L.E., Worrall D., Shelton D.R., Lukaszewski A.J. 1993: Comparative flour quality and protein characteristics of $1 \mathrm{BL} / 1 \mathrm{RS}$ and 1AL/1RS wheat-rye translocation lines. J. Cereal Sci. 17: $95-106$.

34. Xynias I.N., Kozub N.O., Sozinov I.A., Sozinov A.A. 2007: Biochemical markers in wheat breeding. Intern. J. Plant Breed. 1: 1-9.

Received 28.07.08 